\title{
End-cap Group Engineering of a Small Molecule Non-Fullerene Acceptor: The Influence of Benzothiophene Dioxide
}

\author{
Hongda Cao, ${ }^{\dagger, \uparrow \odot ~ N i c o l e ~ B a u e r, ~}{ }^{\dagger, \S}$ Chao Pang, ${ }^{\perp, \|_{\odot}}$ Jeromy Rech, ${ }^{\S}$ Wei You, ${ }^{\S}$ and Paul A. Rupar ${ }^{*},{ }^{\ddagger}$ \\ ${ }^{\ddagger}$ Department of Chemistry and Biochemistry and "Center for Materials for Information Technology (MINT), The University of \\ Alabama, Tuscaloosa, Alabama 35487, United States \\ ${ }^{\S}$ Department of Chemistry, University of North Carolina at Chapel Hill, Chapel Hill, North Carolina 27599, United States \\ ${ }^{\perp}$ State Key Laboratory of Materials-Oriented Chemical Engineering, College of Chemical Engineering, Nanjing Tech University, \\ Nanjing, Jiangsu 210009, P. R. China
}

ABSTRACT: In this study, a sulfonyl-containing end-capping moiety, benzothiophene dioxide, was selected to prepare the nonfullerene acceptor ITBC. ITBC has an acceptor-donoracceptor (A-D-A) structure, with indacenodithieno[3,2-b]thiophene (IDTT) as the electron-rich core moiety. The strong electron-withdrawing sulfonyl acceptor units leads to extended $\mathrm{UV}-$ vis absorption into the near-IR region and relatively low frontier molecular orbital energy levels (LUMO/HOMO: -4.13

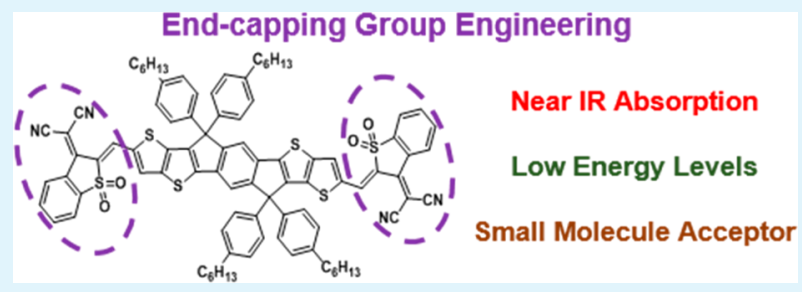
$\mathrm{eV} /-5.61 \mathrm{eV})$ with a narrow bandgap of $1.48 \mathrm{eV}$. These values compare favorably to the well-studied small molecule acceptor 2-(3-oxo-2,3-dihydroinden-1-ylidene)malononitrile end-capped indacenodithieno[3,2-b] thiophene (ITIC). A power conversion efficiency of $4.17 \%$ was achieved by fabricating organic solar cells with the fluorinated conjugated polymer FTAZ as the donor and ITBC as the acceptor. These results indicate that benzothiophene dioxide is a novel electron-withdrawing end-capping unit for ITBC, and can be used as an electron acceptor for organic solar cells.

KEYWORDS: organic solar cells, non-fullerene acceptor, benzothiophene dioxide, fused conjugated system, efficient photovoltaics

\section{INTRODUCTION}

Research into organic solar cells (OSCs) has been rapidly growing over the past decade because of their relatively low cost, flexible structure, and good processability. ${ }^{1-4}$ Bulkheterojunction $(\mathrm{BHJ})$ OSCs, which consist of mixed electron donor and acceptor materials, are one of the most widely used architectures and power conversion efficiencies (PCEs) up to $14 \%$ have been achieved based on this design. ${ }^{5}$ Typically, fullerene materials such as phenyl-C71-butyric acid methyl ester $\left(\mathrm{PC}_{71} \mathrm{BM}\right)$ and phenyl-C61-butyric acid methyl ester $\left(\mathrm{PC}_{61} \mathrm{BM}\right)$ are selected as the acceptor materials; however, some of the intrinsic properties of fullerene derivatives (such as weak absorption, poor tunability, and high cost) can limit the performance of OSCs. ${ }^{6,7}$ In an effort to replace fullerene-based acceptors, nonfullerene electron acceptor (NFA) materials have been recently developed that exhibit comparable and even superior performance to fullerene materials. ${ }^{8-11}$

Small-molecule NFAs have several advantages over polymer NFAs, including better control of reproducibility and easier purification. ${ }^{10-13}$ Recently, NFAs with an acceptor-donoracceptor (A-D-A) structure have been developed that are the among the highest-performing acceptor materials to date. Commonly used fused-ring ladder core moieties include IDT and IDTT, ${ }^{14-18}$ which have broad absorption, good charge transfer, and suitable energy levels to match known donor materials. ${ }^{19}$ Adding the strongly electron withdrawing 2-(3- oxo-2,3-dihydroinden-1-ylidene)malononitrile (INCN) as the end-capping acceptor moiety to the IDTT core yields excellent materials, such as ITIC. ITIC-based organic solar cells show parallel or improved performance relative to fullerene derivatives. $^{20-23}$

To further improve the performance of IDTT-based NFAs, synthetic methods have been developed that include extending the conjugation of IDTT, ${ }^{24-26}$ side-chain engineering on the IDTT moiety, ${ }^{27-30}$ and end-capping IDTT with different electron-withdrawing units (Figure 1). ${ }^{31-33}$ Among these methods, end-cap engineering is the most easily accessible way to tune the properties of NFAs. For example, the absorption spectrum and energy levels of IDTT-containing NFAs can be better matched with donor components by altering the commonly used end-capping unit INCN. In a report by $\mathrm{Li}$ et al., electron-donating methyl groups were introduced on each INCN moiety to produce IT-M and ITDM, which causes a small increase in energy levels to better match the polymer donor while maintaining the favorable molecular packing. ${ }^{34}$ In addition to electron-rich functional groups, electron-withdrawing groups such as fluorine can also be used for end-cap engineering. ${ }^{33}$ For example, Zhao et al.

Received: September 18, 2018

Accepted: November 21, 2018

Published: December 6, 2018 


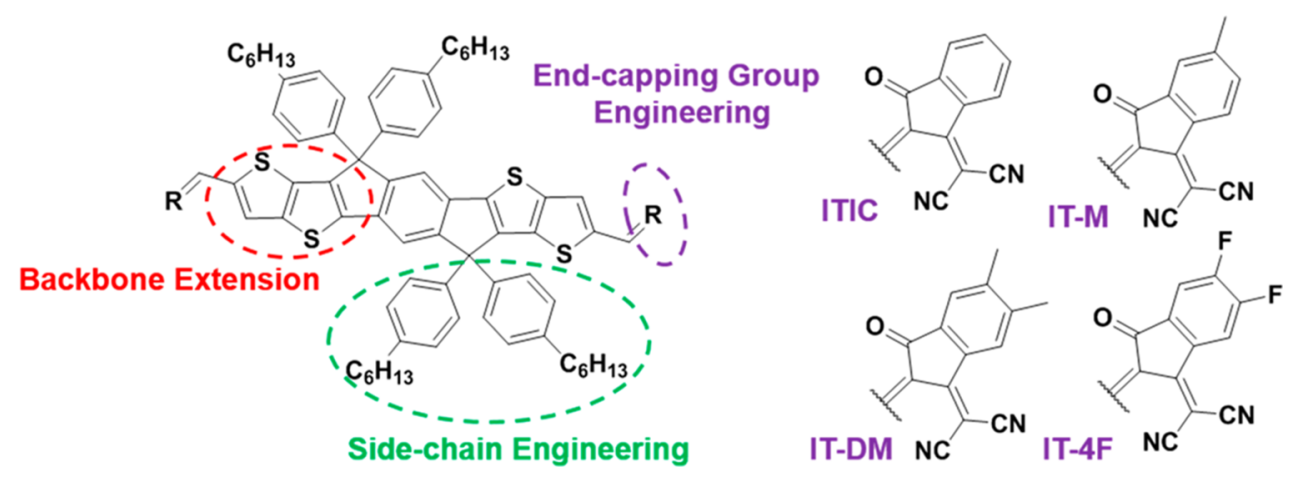

Figure 1. Tunable structures of IDTT-based NFAs.
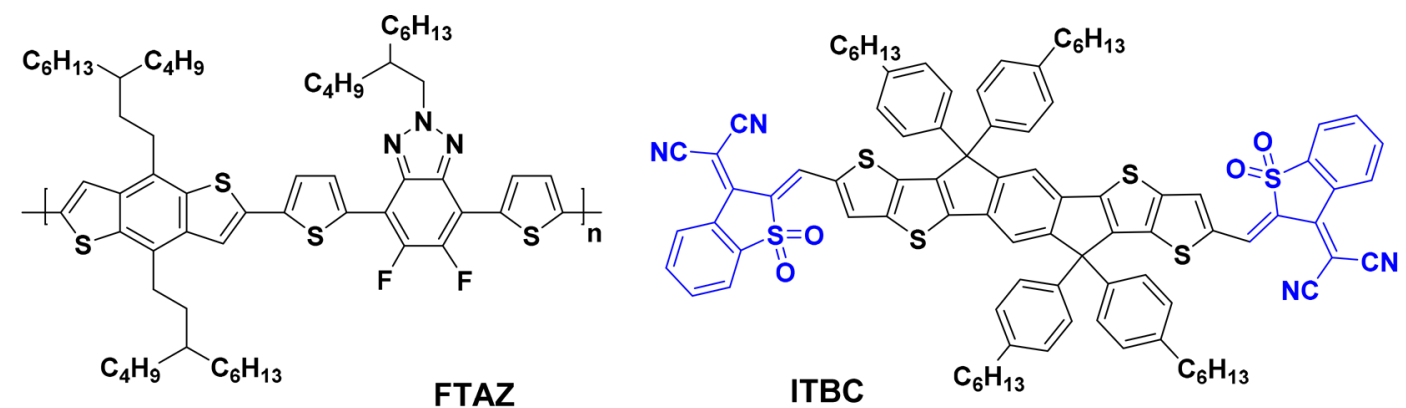

Figure 2. Chemical structures of FTAZ and ITBC.

added two fluorine atoms to each INCN moiety to produce IT-4F, resulting in deeper energy levels and an enhanced absorption range, leading to a PCE of $13.1 \%$ in an OSC device. $^{33}$

Although benzothiophene dioxide has been used for preparing commercial dyes since 1960, its application in OSCs has yet to be explored. ${ }^{35}$ In comparison with the commonly used end-capping unit INCN, benzothiophene dioxide is more electron-deficient due to the replacement of the ketone with a sulfonyl group. It also has a red-shifted absorption spectrum via UV-vis spectroscopy compared to INCN, and can potentially be an efficient end-capping unit to prepare NFA materials. ${ }^{36}$ Herein, we report the first benzothiophene dioxide end-capped NFA material, named ITBC, which possesses a broad absorption from the visible to the near IR regions and low frontier energy levels (LUMO and HOMO), as well as a small bandgap. We have chosen the fluorinated conjugated polymer FTAZ as the polymer donor due to its strong absorption from 400 to $600 \mathrm{~nm}$ and excellent device performance matched with other NFAs. ${ }^{37-40}$ OSCs based on the polymeric donor FTAZ with ITBC as the acceptor (Figure 2) exhibited PCEs up to $4.17 \%$, indicating the potential abilities of ITBC as a NFA material.

\section{EXPERIMENTAL SECTION}

All manipulations were carried out under an anhydrous $\mathrm{N}_{2}$ atmosphere using standard Schlenk line and glovebox techniques. Solvents were dried by passing through an alumina column and then stored over 4 A molecular sieves. All other chemicals were purchased commercially and used as received. Benzo[b]thiophene- $3(2 \mathrm{H})$-one 1,1-dioxide (1) was synthesized according to the literature. ${ }^{35,41}$ IDTT-CHO was purchased from Derthon OPV Co Ltd. (Shenzhen, China) and used directly without any further purification.

Synthesis of 3-dicyanomethylene-benzo[b]thiophene 1,1dioxide (BC). Compound $1(1.82 \mathrm{~g}, 10.0 \mathrm{mmol})$ and malononitrile $(1.32 \mathrm{~g}, 20.0 \mathrm{mmol})$ were dissolved in absolute ethanol $(50.0 \mathrm{~mL})$, and the solution mixture was stirred for $30 \mathrm{~min}$ at $20^{\circ} \mathrm{C}$. Then, anhydrous sodium acetate $(1.23 \mathrm{~g}, 15.0 \mathrm{mmol})$ was added. The color of the solution immediately changed from transparent to yellow. After stirring for an additional $2 \mathrm{~h}$ at room temperature, water $(100 \mathrm{~mL})$ was added into the mixture, and the $\mathrm{pH}$ of the solution was adjusted to $\mathrm{pH} 1-2$ by adding concentrated $\mathrm{HCl}$ dropwise. The resulting suspension was filtered under vacuum and washed with water $(4 \times$ $50.0 \mathrm{~mL}$ ), and the residue was recrystallized with dry ethanol twice, giving BC as a pale yellow solid (0.962 g, 42.0\% yield). ${ }^{1} \mathrm{H}$ NMR (360 $\left.\mathrm{MHz}_{\mathrm{CDCl}} \mathrm{CD}_{3}\right): \delta 4.53(\mathrm{~s}, 2 \mathrm{H}), 7.86-7.97(\mathrm{~m}, 3 \mathrm{H}), 8.66(\mathrm{~d}, J=3.6$ $\mathrm{Hz}, 1 \mathrm{H}) ;{ }^{13} \mathrm{C}$ NMR $\left(125.7 \mathrm{MHz}, \mathrm{CDCl}_{3}\right): \delta 157.99,144.22,138.96$, 135.05, 129.54, 126.72, 123.20, 111.62, 111.56, 107.94, 82.74, 56.65; HRMS (EI, $[\mathrm{M}+], \mathrm{C}_{11} \mathrm{H}_{6} \mathrm{~N}_{2} \mathrm{O}_{2} \mathrm{~S}$ ): calcd, 230.0150; found, 230.0148; Elemental anal. (\%) Cald for $\mathrm{C}_{11} \mathrm{H}_{6} \mathrm{~N}_{2} \mathrm{O}_{2} \mathrm{~S}$ : C 57.38, H 2.63 Found: C 57.22, H 2.65 .

Synthesis of ITBC. Under the protection of $\mathrm{N}_{2}$, IDTT-CHO (110 $\mathrm{mg}, 0.100 \mathrm{mmol})$ and $\mathrm{BC}(230 \mathrm{mg}, 1.00 \mathrm{mmol})$ were added to acetic anhydride $(30.0 \mathrm{~mL})$. The reaction was then stirred at $90{ }^{\circ} \mathrm{C}$ for $24 \mathrm{~h}$. After being cooled to room temperature, the reaction mixture was poured into methanol $(200 \mathrm{~mL})$ and filtered. The solid residue was purified by silica gel column chromatography by using a mixture of dichloromethane/hexane $(\mathrm{v} / \mathrm{v}=1: 1)$ as the eluent to yield the product as a deep blue solid $(88.0 \mathrm{mg}$, yield $59.0 \%) .{ }^{1} \mathrm{H}$ NMR $(360$ $\left.\mathrm{MHz}, \mathrm{CDCl}_{3}\right): \delta 0.85(\mathrm{~m}, 12 \mathrm{H}), 1.19-1.38(\mathrm{~m}, 24 \mathrm{H}), 1.58(\mathrm{~m}, 8 \mathrm{H})$, $2.56(\mathrm{t}, J=7.2 \mathrm{~Hz}, 8 \mathrm{H}), 7.13(\mathrm{~m}, 16 \mathrm{H}), 7.65(\mathrm{~s}, 2 \mathrm{H}), 7.84(\mathrm{~m}, 4 \mathrm{H})$, $7.97(\mathrm{~d}, J=7.2 \mathrm{~Hz}, 2 \mathrm{H}), 8.55(\mathrm{~s}, 4 \mathrm{H}), 8.82(\mathrm{~d}, J=7.2 \mathrm{~Hz}, 2 \mathrm{H}) ;{ }^{13} \mathrm{C}$ NMR $\left(125.7 \mathrm{MHz}, \mathrm{CDCl}_{3}\right): \delta 155.98,153.07,151.20,147.47$, $146.45,145.07,142.92,138.82,137.28,135.97,135.33,134.90$, $134.90,134.57,133.12,129.50,129.50,129.18,127.94,126.45$, $125.97,122.41,118.95,114.75,114.66,71.09,63.42,35.82,31.91$, 31.44, 29.39, 22.80, 14.30; MS-MALDI $\left([\mathrm{M}+\mathrm{H}]^{+}, \mathrm{C}_{92} \mathrm{H}_{82} \mathrm{~N}_{4} \mathrm{O}_{4} \mathrm{~S}_{6}\right)$ : 1499.4691; Elemental anal. (\%). Calcd for $\mathrm{C}_{92} \mathrm{H}_{82} \mathrm{~N}_{4} \mathrm{O}_{4} \mathrm{~S}_{6}: \mathrm{C} 73.66, \mathrm{H}$ 5.51. Found: C 73.25 , H 5.87 .

\section{RESULTS AND DISCUSSION}

Material Synthesis and Characterization. FTAZ $\left(M_{\mathrm{n}}=\right.$ $\left.60 \mathrm{~kg} \mathrm{~mol}{ }^{-1} ; M_{\mathrm{w}} / M_{\mathrm{n}}=1.9\right)$ was synthesized according to methods previously reported in literature. ${ }^{42}$ The synthesis of 
Scheme 1. Synthesis of ITBC
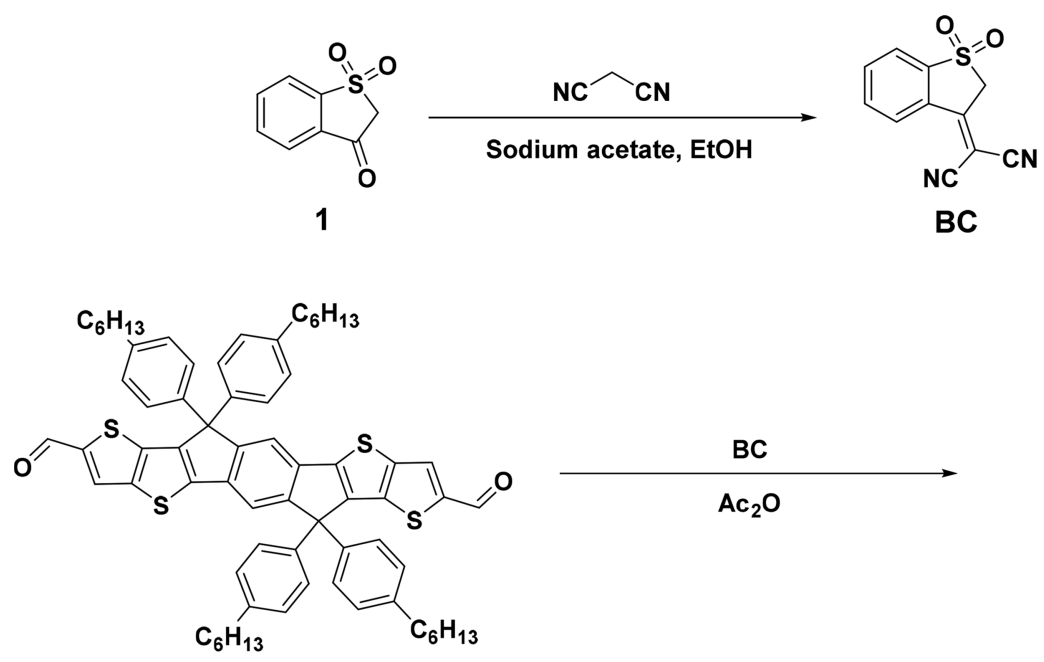

ITBC

IDTT-CHO
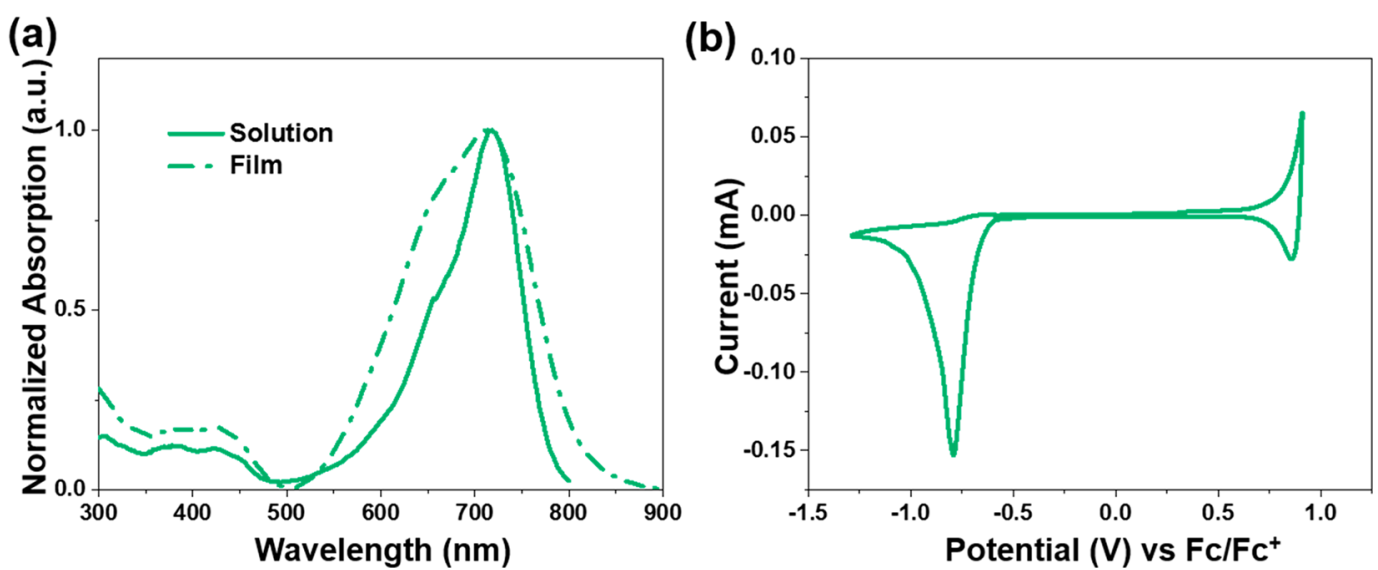

Figure 3. (a) UV-vis absorption spectra of ITBC in chloroform and of thin film. (b) Cyclic voltammogram of ITBC in a $0.1 \mathrm{M}$ acetonitrile solution of $\mathrm{Bu}_{4} \mathrm{NClO}_{4}$ at a scan rate of $0.1 \mathrm{~V} \mathrm{~s}^{-1}$.

Table 1. Photophysical and Electrochemical Data

$\begin{array}{ccccccccc}\text { compd } & \lambda_{\mathrm{ab}, \text { sol }}{ }^{a}(\mathrm{~nm}) & \lambda_{\mathrm{ab}, \text { film }}(\mathrm{nm}) & \varepsilon^{b}\left(\mathrm{~cm}^{-1} \mathrm{M}^{-1}\right) & \lambda_{\text {onset }}(\mathrm{nm}) & {\text { bandgap }{ }_{\text {opt }}{ }^{c}(\mathrm{eV})}_{\text {bandgap }_{\text {cv }}{ }^{d}(\mathrm{eV})} & \mathrm{LUMO}^{d}(\mathrm{eV}) & \mathrm{HOMO}^{d}(\mathrm{eV}) \\ \text { ITBC } & 718 & 718 & 1.55 \times 10^{5} & 809 & 1.53 & 1.48 & -4.13 & -5.61\end{array}$

${ }^{a}$ In chloroform $\left(1 \times 10^{-5} \mathrm{M}\right) .{ }^{b}$ Calculated at maximum absorption in chloroform solution. ${ }^{c}$ Calculated from thin film, bandgap $=1240 / \lambda_{\text {onset }}$. ${ }^{d}$ ITBC was measured by casting a film on a working electrode in a $0.1 \mathrm{M}$ solution of $\mathrm{Bu}_{4} \mathrm{NClO}_{4}$ in acetonitrile at a scan rate of $0.1 \mathrm{~V} \mathrm{~s}{ }^{-1}, E_{\mathrm{ox}}\left(\mathrm{E}_{\text {red }}\right)$ estimated from oxidation (reduction) onset potentials vs ferrocene/ferrocenium, HOMO/LUMO $=-\left(E_{\mathrm{ox}} / E_{\mathrm{red}}+4.8 \mathrm{eV}\right) .{ }^{44}$

ITBC is shown in Scheme 1. Benzo[b]thiophene-3(2H)-one 1,1-dioxide (1) was prepared using a procedure reported by Gueye et al. ${ }^{43}$ The key intermediate 3-dicyanomethylenebenzo[b]thiophene 1,1-dioxide (BC) was obtained by adding malononitrile into an ethanol solution of compound $\mathbf{1}$ with a moderate yield of $42 \%$. Finally, a Knoevenagel condensation reaction was performed on IDTT-CHO and $\mathrm{BC}$ to produce ITBC with $59 \%$ yield. ITBC is soluble in chloroform, THF, and chlorobenzene. The thermal stability was evaluated by thermogravimetric analysis (TGA), which showed a 5\% weight loss temperature at $212{ }^{\circ} \mathrm{C}$ (Figure S2).

Optical and Electrochemical Properties. UV-Vis absorption spectra of ITBC in chloroform and in a thin film are shown in Figure 3a, and the absorption maximum and optical band gap of ITBC are summarized in Table 1. In chloroform, ITBC has a strong absorption from 500 to $800 \mathrm{~nm}$ with a maximum extinction coefficient of $1.55 \times 10^{5} \mathrm{~cm}^{-1} \mathrm{M}^{-1}$ at $718 \mathrm{~nm}$. ITBC thin films exhibit a broader absorption spectrum relative to ITBC in solution; we attribute this to potential self-aggregation of ITBC. The optical bandgap of ITBC in the film was calculated to be $1.53 \mathrm{eV}$. Compared to films of ITIC, the absorption $\lambda_{\max }$ of ITBC is red-shifted ca. 16 $\mathrm{nm}$, which is consistent with literature reports that the $\mathrm{BC}$ moiety is more electron-withdrawing than the INCN unit. ${ }^{20}$

The electrochemical properties of a thin film of ITBC were measured with cyclic voltammetry (Figure $3 \mathrm{~b}$ ). The HOMO and LUMO energy levels of ITBC were estimated from the oxidation and reduction onsets, with ferrocene/ferrocenium as the external reference (assuming $-4.8 \mathrm{eV}$ vs vacuum). ${ }^{44}$ ITBC exhibits a LUMO of $-4.13 \mathrm{eV}$ and HOMO of $-5.61 \mathrm{eV}$ with a narrow bandgap of $1.48 \mathrm{eV}$, which is consistent with the optical bandgap of $1.53 \mathrm{eV}$ measured on ITBC thin films. ITBC has 


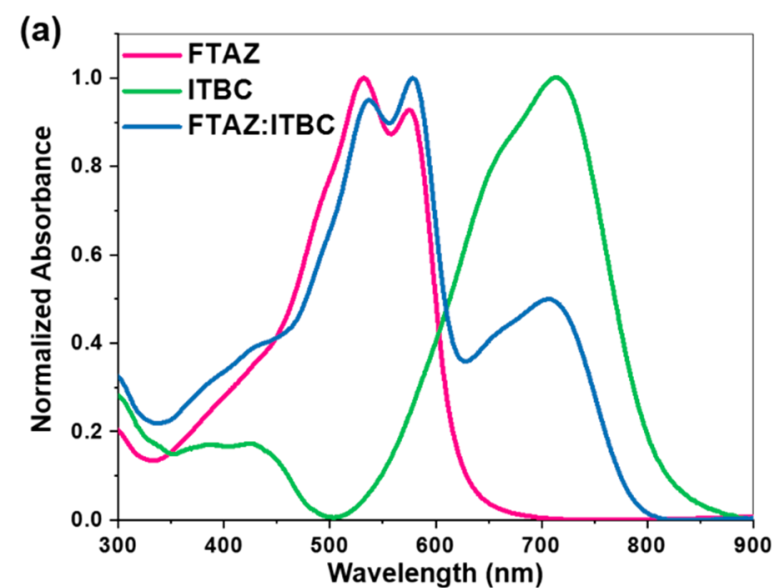

(c)

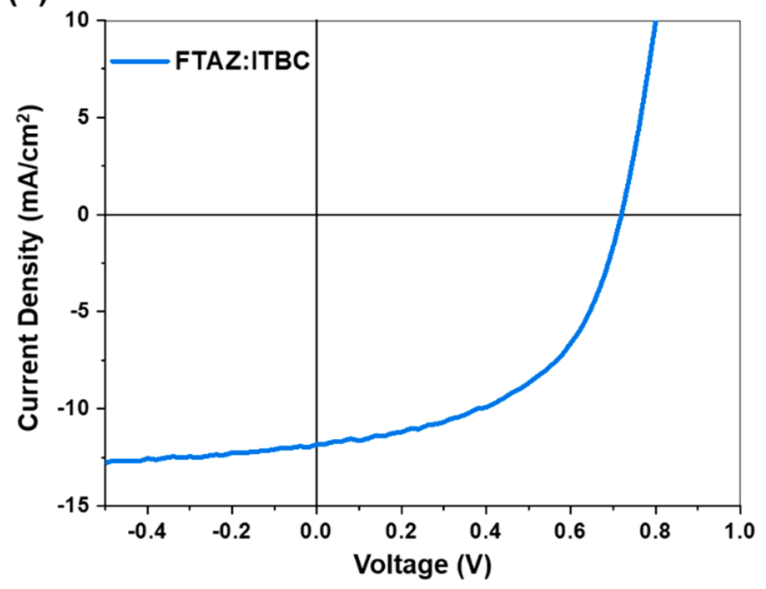

(b)

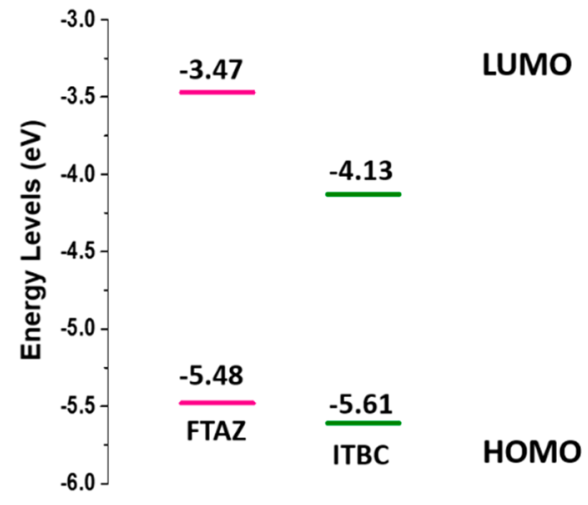

(d)

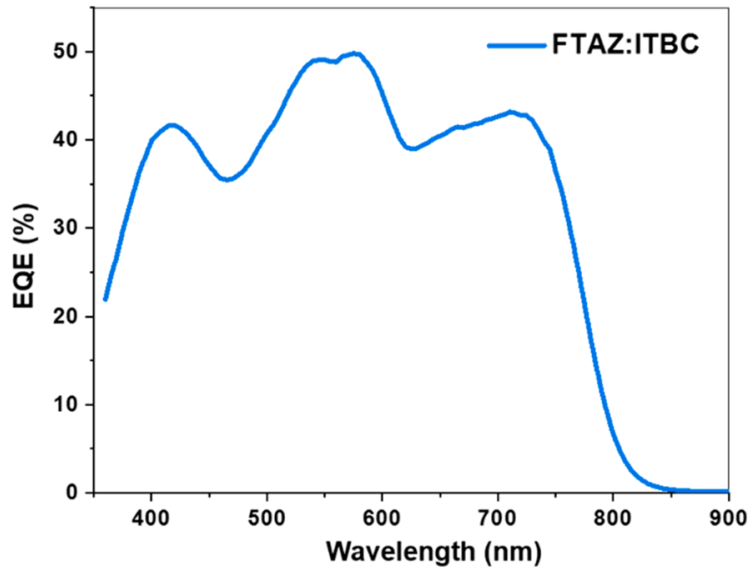

Figure 4. (a) Film absorbance for neat FTAZ, neat ITBC, and blend (on glass); (b) energy levels of FTAZ and ITBC; optimized (c) J-V curve and (d) EQE spectra of FTAZ:ITBC-based BHJ devices.

Table 2. Optimal Photovoltaic Characteristics of FTAZ:ITBC-Based Solar Cells

\begin{tabular}{ccccc} 
thickness $(\mathrm{nm})$ & $J_{\mathrm{sc}}\left(\mathrm{mA} / \mathrm{cm}^{2}\right)$ & $V_{\mathrm{oc}}(\mathrm{V})$ & $\mathrm{FF}(\%)$ & PCE (\%) \\
50 & $11.89 \pm 0.21$ & $0.716 \pm 0.004$ & $49.0 \pm 1.4$ & $4.17 \pm 0.20$ \\
\hline
\end{tabular}

deeper energy levels and a smaller bandgap compared to ITIC $(-3.83 /-5.48 \mathrm{eV}){ }^{20}$ and is similar to IT-4F $(-4.14 /-5.66$ $\mathrm{eV}){ }^{33}$ IT-4F has been reported as one of the best performing NFAs, which is partially attributed to its low energy levels. However, the synthesis of IT-4F includes several difficult fluorination steps and it is typically synthesized in low yields. As such, ITBC offers improvements compared to IT-4F, as its simple, high-yielding synthesis yields comparable frontier molecular orbital energy levels. ${ }^{33,45}$

Photovoltaic Properties. The fluorinated conjugated polymer FTAZ (Figure 2) was selected as the donor material to partner with ITBC in an OSC. FTAZ's energy levels (LUMO/HOMO: $-3.47 / 5.48 \mathrm{eV}$ ) match well with ITBC, and its strong absorption from 400 to $600 \mathrm{~nm}$ is complementary with the UV-vis spectrum of ITBC. ${ }^{24,42,46}$ The film UV-vis absorption of neat FTAZ and ITBC and their blend film (1:1 ratio) are shown in Figure 4a. The blend film exhibited a broad absorption spectrum from $300 \mathrm{~nm}$ in the UV region to $800 \mathrm{~nm}$ in the near IR region. The difference between the LUMO energy level of FTAZ and the LUMO energy level of ITBC is $0.66 \mathrm{eV}$ (Figure $4 \mathrm{~b}$ ), which provides driving force to overcome the binding energy of the exciton. ${ }^{47}$
To investigate the potential of ITBC as an NFA acceptor for OSC application, we prepared inverted bulk heterojunction (BHJ) OSCs with the structure of ITO/ZnO/FTAZ:ITBC/ $\mathrm{MoO}_{3} / \mathrm{Al}$. The OSC devices were optimized by varying the fabrication conditions (i.e., blend ratios of FTAZ and ITBC, film thickness, and processing solvents), and the corresponding data are summarized in Tables $\mathrm{S} 1-\mathrm{S} 4$. The optimal PCE obtained from these devices is $4.17 \%$ (Table 2), and its corresponding $J-V$ curve is depicted in Figure 4c. One possible reason for the relatively lower device performance is that the sulfonyl functional group of the end-capping moiety has the oxygen atoms orthogonal to the plane of the backbone. This could lead to expanded $\pi-\pi$ stacking distances between acceptor molecules and affect the efficient charge transfer. The external quantum efficiency (EQE) spectra of the optimal device was also measured (Figure 4d). The FTAZ:ITBC device exhibited a strong and broad photo response from 450 to $750 \mathrm{~nm}$, with a maximum response of $50 \%$ around $580 \mathrm{~nm}$.

Photoluminescence Study. To better understand the exciton dissociation and charge transfer in the FTAZ: ITBC blend, photoluminescence (PL) quenching experiments were performed. The PL spectra of neat FTAZ (excited at $510 \mathrm{~nm}$ ), neat ITBC (excited at $705 \mathrm{~nm}$ ) and BHJ blend film (excited at 
(a)

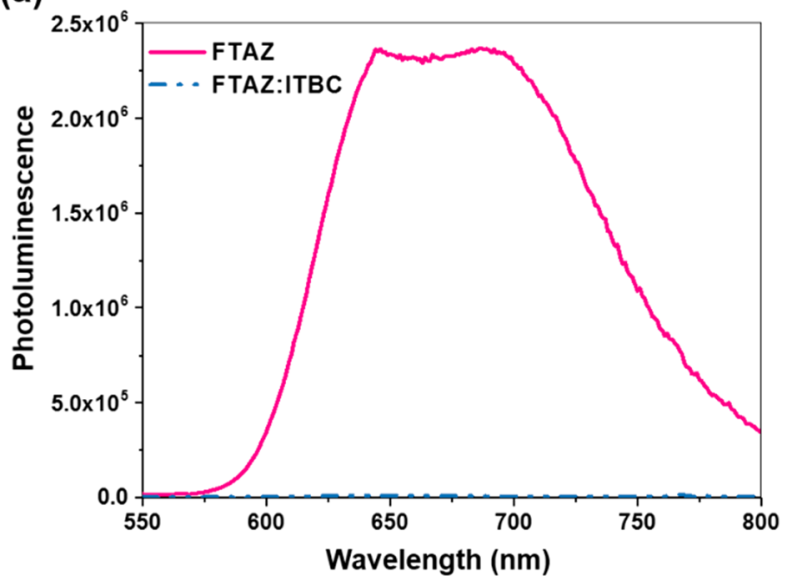

(b)

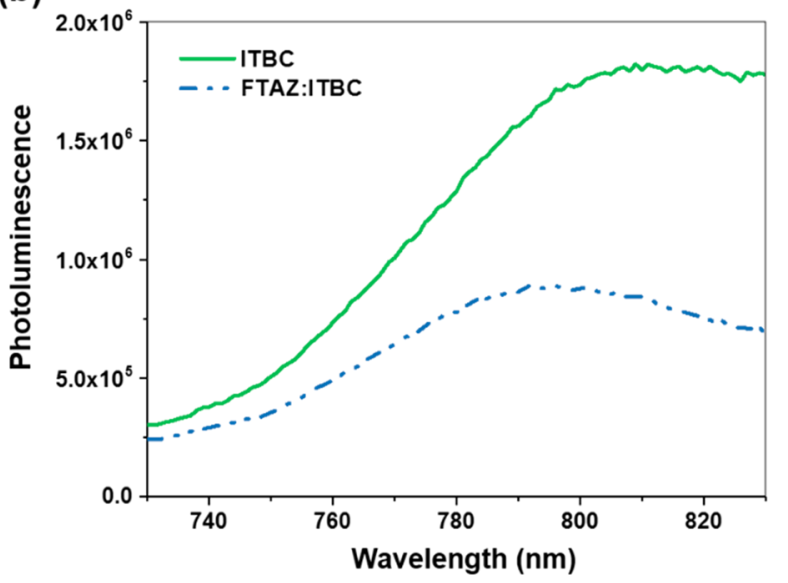

Figure 5. Photoluminescence of (a) neat FTAZ and BHJ blend film (excitation at $510 \mathrm{~nm}$ ) and (b) neat ITBC and BHJ blend film (excitation at $705 \mathrm{~nm})$.

510 and $705 \mathrm{~nm}$ ) are shown in Figure 5. As shown in Figure $5 \mathrm{a}$, the photoluminescence of FTAZ is quenched nearly completely by ITBC in the blend film. This suggests that there is efficient transfer of electrons from FTAZ to ITBC in the $\mathrm{BHJ}$. However, it is clear from Figure $5 \mathrm{~b}$ that FTAZ does not fully quench the photoluminescence of ITBC. This incomplete quenching indicates that there may be an issue with hole transfer from ITBC to FTAZ, which could lead to geminate recombination and decrease the device performance.

Mobility Measurement. To further investigate the charge transport properties of the neat ITBC and FTAZ:ITBC blend, hole only (ITO/PEDOT:PSS/FTAZ:ITBC/ $\mathrm{MoO}_{3} / \mathrm{Al}$ ) and electron only (ITO/ZnO/FTAZ:ITBC/Ca/Al) devices were fabricated to measure the charge mobilities via the space charge limited current (SCLC) method. From the hole only device, the hole mobility in the blend was measured to be $(8.18 \pm 2.08) \times 10^{-4} \mathrm{~cm}^{2} \mathrm{~V}^{-1} \mathrm{~s}^{-1}$, which is similar to other FTAZ:NFA systems. ${ }^{46,48-50}$ The electron-only devices based on both the neat ITBC and FTAZ:ITBC blend films displayed extremely low current density values and did not reach the SCLC range (Figure S1); consequently, we were unable to determine electron mobility values. This suggests that ITBC may have a low electron mobility, which can increase the amount of bimolecular recombination and lead to a lower FF. This is consistent with the results we obtained for these FTAZ:ITBC devices.

Film Morphology. The morphology of the active layer is crucial in the performance of OSC devices, especially the exciton dissociation and the charge transfer properties. ${ }^{51}$ The surface morphology information such as phase separation and surface roughness can be investigated by atomic force microscopy (AFM). ${ }^{52}$ Typically, a smooth morphology of the blend film with small root-mean-square (RMS) roughness is beneficial for the contact between the active layer and electrode, which leads to good device performance. ${ }^{52}$ The surface morphology of FTAZ:ITBC blend films were studied via AFM, and as shown in Figure 6, the blend film has a rough surface with a RMS roughness of $2.47 \mathrm{~nm}$. Compared with other FTAZ:NFA containing systems, FTAZ:ITBC showed a higher roughness value, which could also contribute to the relatively low device performance. ${ }^{24,49,53}$

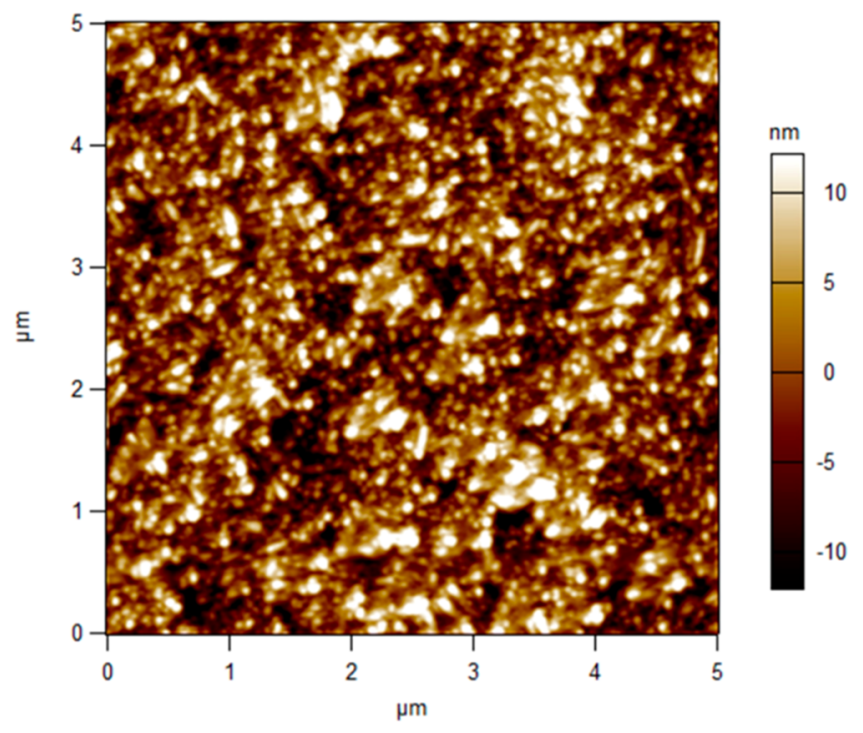

Figure 6. AFM image of the blend films $(1: 1, w / w)$.

\section{CONCLUSIONS}

In summary, the use of benzothiophene dioxide as the endcapping group for a nonfullerene acceptor has been investigated for the first time with the synthesis of the novel small-molecule acceptor ITBC. The electron-withdrawing benzothiophene dioxide moiety gives ITBC a near IR absorption and low frontier energy levels, providing a new and simple approach to achieve red-shifted absorption and reduced energy levels compared to other end-cap engineering methods such as the introduction of fluorine by multiple step synthesis.

The performance of ITBC as a nonfullerene acceptor in organic solar cells was examined by fabricating devices with the fluorinated polymer FTAZ. These two materials have complementary absorption, and the blend of FTAZ and ITBC afforded an optimized PCE of $4.17 \%$ with a $V_{\text {oc }}$ of 0.716 $\mathrm{V}$, a $J_{\mathrm{sc}}$ of $11.89 \mathrm{~mA} / \mathrm{cm}^{2}$, and a FF of 0.490 . The PL quenching, mobility, and morphology were also investigated to further understand the performance of these ITBC-based OSCs. These results demonstrate the potential abilities of ITBC as an electron acceptor in nonfullerene OSCs. 


\section{ASSOCIATED CONTENT}

\section{S Supporting Information}

The Supporting Information is available free of charge on the ACS Publications website at DOI: 10.1021/acsaem.8b01576.

NMR spectra and solar cell device fabrication details (PDF)

\section{AUTHOR INFORMATION}

\section{Corresponding Author}

*E-mail: parupar@ua.edu.

\section{ORCID}

Hongda Cao: 0000-0002-0313-7956

Chao Pang: 0000-0002-1633-7009

Wei You: 0000-0003-0354-1948

Paul A. Rupar: 0000-0002-9532-116X

\section{Author Contributions}

${ }^{\dagger}$ H.C. and N.B. contributed equally. H.C. was responsible for the materials synthesis and N.B. was responsible for the device fabrication.

\section{Notes}

The authors declare no competing financial interest.

\section{ACKNOWLEDGMENTS}

H.C. and P.A.R. thank the National Science Foundation (Grant CHE-1507566) and the University of Alabama for financial support. N.B., J.R., and W.Y. thank the NSF (CBET1639429) for financial support. We also thank Stephanie Samson and the Gerald Meyer lab at UNC for assistance with the PL measurements.

\section{REFERENCES}

(1) Cai, Y.; Huo, L.; Sun, Y. Recent Advances in Wide-Bandgap Photovoltaic Polymers. Adv. Mater. 2017, 29, 1605437.

(2) Xiao, S.; Zhang, Q.; You, W. Molecular Engineering of Conjugated Polymers for Solar Cells: An Updated Report. Adv. Mater. 2017, 29, 1601391.

(3) Lu, L.; Zheng, T.; Wu, Q.; Schneider, A. M.; Zhao, D.; Yu, L. Recent Advances in Bulk Heterojunction Polymer Solar Cells. Chem. Rev. 2015, 115, 12666-12731.

(4) Dou, L.; Liu, Y.; Hong, Z.; Li, G.; Yang, Y. Low-Bandgap NearIR Conjugated Polymers/Molecules for Organic Electronics. Chem. Rev. 2015, 115, 12633-12665.

(5) Zhang, S.; Qin, Y.; Zhu, J.; Hou, J. Over 14\% Efficiency in Polymer Solar Cells Enabled by a Chlorinated Polymer Donor. Adv. Mater. 2018, 30, 1800868.

(6) Liu, T.; Troisi, A. What Makes Fullerene Acceptors Special as Electron Acceptors in Organic Solar Cells and How to Replace Them. Adv. Mater. 2013, 25, 1038-1041.

(7) Zhan, C. L.; Zhang, X. L.; Yao, J. N. New Advances in NonFullerene Acceptor Based Organic Solar Cells. RSC Adv. 2015, 5, 93002-93026.

(8) Lin, Y. Z.; Zhan, X. W. Designing Efficient Non-Fullerene Acceptors by Tailoring Extended Fused-Rings with Electron-Deficient Groups. Adv. Energy Mater. 2015, 5, 1501063.

(9) Li, S.; Liu, W.; Li, C. Z.; Shi, M.; Chen, H. Efficient Organic Solar Cells with Non-Fullerene Acceptors. Small 2017, 13, 1701120.

(10) Hou, J.; Inganas, O.; Friend, R. H.; Gao, F. Organic Solar Cells Based on Non-Fullerene Acceptors. Nat. Mater. 2018, 17, 119-128.

(11) Yan, C.; Barlow, S.; Wang, Z.; Yan, H.; Jen, A. K. Y.; Marder, S. R.; Zhan, X. Non-Fullerene Acceptors for Organic Solar Cells. Nat. Rev. Mater. 2018, 3, 18003.

(12) Zhou, N.; Lin, H.; Lou, S. J.; Yu, X.; Guo, P.; Manley, E. F.; Loser, S.; Hartnett, P.; Huang, H.; Wasielewski, M. R.; Chen, L. X.; Chang, R. P. H.; Facchetti, A.; Marks, T. J. Morphology-Performance
Relationships in High-Efficiency All-Polymer Solar Cells. Adv. Energy Mater. 2014, 4, 1300785.

(13) Eastham, N. D.; Logsdon, J. L.; Manley, E. F.; Aldrich, T. J.; Leonardi, M. J.; Wang, G.; Powers-Riggs, N. E.; Young, R. M.; Chen, L. X.; Wasielewski, M. R.; Melkonyan, F. S.; Chang, R. P. H.; Marks, T. J. Hole-Transfer Dependence on Blend Morphology and Energy Level Alignment in Polymer: ITIC Photovoltaic Materials. Adv. Mater. 2018, 30, 1704263.

(14) Chen, S.; Liu, Y.; Zhang, L.; Chow, P. C. Y.; Wang, Z.; Zhang, G.; Ma, W.; Yan, H. A Wide-Bandgap Donor Polymer for Highly Efficient Non-fullerene Organic Solar Cells with a Small Voltage Loss. J. Am. Chem. Soc. 2017, 139, 6298-6301.

(15) Holliday, S.; Ashraf, R. S.; Wadsworth, A.; Baran, D.; Yousaf, S. A.; Nielsen, C. B.; Tan, C. H.; Dimitrov, S. D.; Shang, Z.; Gasparini, N.; Alamoudi, M.; Laquai, F.; Brabec, C. J.; Salleo, A.; Durrant, J. R.; McCulloch, I. High-Efficiency and Air-Stable P3HT-based Polymer Solar Cells with a New Non-Fullerene Acceptor. Nat. Commun. 2016, 7,11585 .

(16) Wu, Y.; Bai, H. T.; Wang, Z. Y.; Cheng, P.; Zhu, S. Y.; Wang, Y. F.; Ma, W.; Zhan, X. W. A Planar Electron Acceptor for Efficient Polymer Solar Cells. Energy Environ. Sci. 2015, 8, 3215-3221.

(17) Li, S. X.; Liu, W. Q.; Li, C. Z.; Lau, T. K.; Lu, X. H.; Shi, M. M.; Chen, H. Z. A Non-Fullerene Acceptor with a Fully Fused Backbone for Efficient Polymer Solar Cells with a High Open-Circuit Voltage. J. Mater. Chem. A 2016, 4, 14983-14987.

(18) Swick, S. M.; Zhu, W.; Matta, M.; Aldrich, T. J.; Harbuzaru, A.; Lopez Navarrete, J. T.; Ponce Ortiz, R.; Kohlstedt, K. L.; Schatz, G. C.; Facchetti, A.; Melkonyan, F. S.; Marks, T. J. Closely packed, low reorganization energy $\pi$-extended postfullerene acceptors for efficient polymer solar cells. Proc. Natl. Acad. Sci. U. S. A. 2018, 115, E8341E8348.

(19) Li, Y. X.; Gu, M. C.; Pan, Z.; Zhang, B.; Yang, X. T.; Gu, J. W.; Chen, Y. Indacenodithiophene: A Promising Building Block for High Performance Polymer Solar Cells. J. Mater. Chem. A 2017, 5, 1079810814

(20) Lin, Y.; Wang, J.; Zhang, Z.-G.; Bai, H.; Li, Y.; Zhu, D.; Zhan, $X$. An Electron Acceptor Challenging Fullerenes for Efficient Polymer Solar Cells. Adv. Mater. 2015, 27, 1170-1174.

(21) Zheng, Z.; Awartani, O. M.; Gautam, B.; Liu, D.; Qin, Y.; Li, W.; Bataller, A.; Gundogdu, K.; Ade, H.; Hou, J. Efficient Charge Transfer and Fine-Tuned Energy Level Alignment in a THFProcessed Fullerene-Free Organic Solar Cell with 11.3\% Efficiency. Adv. Mater. 2017, 29, 1604241.

(22) An, M.; Xie, F.; Geng, X.; Zhang, J.; Jiang, J.; Lei, Z.; He, D.; Xiao, Z.; Ding, L. A High-Performance D-A Copolymer Based on Dithieno[3,2-b:2',3'-d]Pyridin-5(4H)-One Unit Compatible with Fullerene and Nonfullerene Acceptors in Solar Cells. Adv. Energy Mater. 2017, 7, 1602509.

(23) Zhao, W.; Qian, D.; Zhang, S.; Li, S.; Inganäs, O.; Gao, F.; Hou, J. Fullerene-Free Polymer Solar Cells with over 11\% Efficiency and Excellent Thermal Stability. Adv. Mater. 2016, 28, 4734-4739.

(24) Dai, S.; Zhao, F.; Zhang, Q.; Lau, T.-K.; Li, T.; Liu, K.; Ling, Q.; Wang, C.; Lu, X.; You, W.; Zhan, X. Fused Nonacyclic Electron Acceptors for Efficient Polymer Solar Cells. J. Am. Chem. Soc. 2017, $139,1336-1343$.

(25) Shi, X.; Zuo, L.; Jo, S. B.; Gao, K.; Lin, F.; Liu, F.; Jen, A. K. Y. Design of a Highly Crystalline Low-Band Gap Fused-Ring Electron Acceptor for High-Efficiency Solar Cells with Low Energy Loss. Chem. Mater. 2017, 29, 8369-8376.

(26) Yi, Y. Q. Q.; Feng, H. R.; Chang, M. J.; Zhang, H. T.; Wan, X. J.; Li, C. X.; Chen, Y. S. New Small-Molecule Acceptors based on Hexacyclic Naphthalene(cyclopentadithiophene) for Efficient NonFullerene Organic Solar Cells. J. Mater. Chem. A 2017, 5, 1720417210.

(27) Gao, W.; An, Q. S.; Ming, R. J.; Xie, D. J.; Wu, K. L.; Luo, Z. H.; Zou, Y.; Zhang, F. J.; Yang, C. L. Side Group Engineering of Small Molecular Acceptors for High-Performance Fullerene-Free Polymer Solar Cells: Thiophene Being Superior to Selenophene. Adv. Funct. Mater. 2017, 27, 1702194. 
(28) Lin, Y.; Zhao, F.; He, Q.; Huo, L.; Wu, Y.; Parker, T. C.; Ma, W.; Sun, Y.; Wang, C.; Zhu, D.; Heeger, A. J.; Marder, S. R.; Zhan, X. High-Performance Electron Acceptor with Thienyl Side Chains for Organic Photovoltaics. J. Am. Chem. Soc. 2016, 138, 4955-4961.

(29) Yang, Y.; Zhang, Z.-G.; Bin, H.; Chen, S.; Gao, L.; Xue, L.; Yang, C.; Li, Y. Side-Chain Isomerization on an n-type Organic Semiconductor ITIC Acceptor Makes 11.77\% High Efficiency Polymer Solar Cells. J. Am. Chem. Soc. 2016, 138, 15011-15018.

(30) Aldrich, T. J.; Swick, S. M.; Melkonyan, F. S.; Marks, T. J. Enhancing Indacenodithiophene Acceptor Crystallinity via Substituent Manipulation Increases Organic Solar Cell Efficiency. Chem. Mater. 2017, 29, 10294-10298.

(31) Yao, H.; Ye, L.; Hou, J.; Jang, B.; Han, G.; Cui, Y.; Su, G. M.; Wang, C.; Gao, B.; Yu, R.; Zhang, H.; Yi, Y.; Woo, H. Y.; Ade, H.; Hou, J. Achieving Highly Efficient Nonfullerene Organic Solar Cells with Improved Intermolecular Interaction and Open-Circuit Voltage. Adv. Mater. 2017, 29, 1700254.

(32) Zhang, Z.; Feng, L.; Xu, S.; Yuan, J.; Zhang, Z.-G.; Peng, H.; Li, Y.; Zou, Y. Achieving Over $10 \%$ Efficiency in a New Acceptor ITTC and its Blends with Hexafluoroquinoxaline based Polymers. J. Mater. Chem. A 2017, 5, 11286-11293.

(33) Zhao, W.; Li, S.; Yao, H.; Zhang, S.; Zhang, Y.; Yang, B.; Hou, J. Molecular Optimization Enables over 13\% Efficiency in Organic Solar Cells. J. Am. Chem. Soc. 2017, 139, 7148-7151.

(34) Li, S.; Ye, L.; Zhao, W.; Zhang, S.; Mukherjee, S.; Ade, H.; Hou, J. Energy-Level Modulation of Small-Molecule Electron Acceptors to Achieve over 12\% Efficiency in Polymer Solar Cells. Adv. Mater. 2016, 28, 9423-9429.

(35) Shenoy, V. U.; Patel, V. P.; Seshadri, S. Disperse Dyes Derived from 3-Oxo-2,3-dihydrobenzo-[itb] thiophene-1,1-dioxide and 3-Dicyanomethylene-2,3-dihydrobenzo [itb] thiophene-1,1-dioxide. Dyes Pigm. 1989, 11, 37-46.

(36) Capbianco, A.; Antonio, E.; Tonino, C.; Fabio, B.; Antonio, C.; Roberto, C.; Peluso, A. Tuning Wavefunction Mixing in Push-Pull Molecules: From Neutral to Zwitterionic Compounds. Eur. J. Org. Chem. 2012, 2012, 2980-2989.

(37) Zhao, F.; Dai, S.; Wu, Y.; Zhang, Q.; Wang, J.; Jiang, L.; Ling, Q.; Wei, Z.; Ma, W.; You, W.; Wang, C.; Zhan, X. Single-Junction Binary-Blend Nonfullerene Polymer Solar Cells with $12.1 \%$ Efficiency. Adv. Mater. 2017, 29, 1700144.

(38) Wang, J.; Wang, W.; Wang, X.; Wu, Y.; Zhang, Q.; Yan, C.; Ma, W.; You, W.; Zhan, X. Enhancing Performance of Nonfullerene Acceptors via Side-Chain Conjugation Strategy. Adv. Mater. 2017, 29, 1702125.

(39) Zhu, J.; Ke, Z.; Zhang, Q.; Wang, J.; Dai, S.; Wu, Y.; Xu, Y.; Lin, Y.; Ma, W.; You, W.; Zhan, X. Naphthodithiophene-Based Nonfullerene Acceptor for High-Performance Organic Photovoltaics: Effect of Extended Conjugation. Adv. Mater. 2018, 30, 1704713.

(40) Dai, S.; Xiao, Y.; Xue, P.; James Rech, J.; Liu, K.; Li, Z.; Lu, X.; You, W.; Zhan, X. Effect of Core Size on Performance of Fused-Ring Electron Acceptors. Chem. Mater. 2018, 30, 5390-5396.

(41) Gubbelmans, E.; Verbiest, T.; Picard, I.; Persoons, A.; Samyn, C. Poly(phenylquinoxalines) for Second-Order Nonlinear Optical Applications. Polymer 2005, 46, 1784-1795.

(42) Price, S. C.; Stuart, A. C.; Yang, L.; Zhou, H.; You, W. Fluorine Substituted Conjugated Polymer of Medium Band Gap Yields 7\% Efficiency in Polymer-Fullerene Solar Cells. J. Am. Chem. Soc. 2011, 133, 4625-4631.

(43) Gueye, R.; Pouget, C.; Champavier, Y.; Buxeraud, J.; Duroux, J.-L.; Fagnère, C. Synthetic Strategies to 2'-Hydroxy-4'-methylsulfonylacetophenone, a Key Compound for the Preparation of Flavonoid Derivatives. C. R. Chim. 2014, 17, 443-449.

(44) Cardona, C. M.; Li, W.; Kaifer, A. E.; Stockdale, D.; Bazan, G. C. Electrochemical Considerations for Determining Absolute Frontier Orbital Energy Levels of Conjugated Polymers for Solar Cell Applications. Adv. Mater. 2011, 23, 2367-2371.

(45) Li, S.; Ye, L.; Zhao, W.; Yan, H.; Yang, B.; Liu, D.; Li, W.; Ade, H.; Hou, J. A Wide Band Gap Polymer with a Deep Highest
Occupied Molecular Orbital Level Enables 14.2\% Efficiency in Polymer Solar Cells. J. Am. Chem. Soc. 2018, 140, 7159-7167.

(46) Bauer, N.; Zhang, Q.; Zhu, J.; Peng, Z.; Yan, L.; Zhu, C.; Ade, H.; Zhan, X.; You, W. Donor Polymer Fluorination Doubles the Efficiency in Non-Fullerene Organic Photovoltaics. J. Mater. Chem. A 2017, 5, 22536-22541.

(47) Scharber, M. C.; Mühlbacher, D.; Koppe, M.; Denk, P.; Waldauf, C.; Heeger, A. J.; Brabec, C. J. Design Rules for Donors in Bulk-Heterojunction Solar Cells-Towards 10\% Energy-Conversion Efficiency. Adv. Mater. 2006, 18, 789-794.

(48) Li, Z.; Dai, S.; Xin, J.; Zhang, L.; Wu, Y.; Rech, J.; Zhao, F.; Li, T.; Liu, K.; Liu, Q.; Ma, W.; You, W.; Wang, C.; Zhan, X. Enhancing the Performance of the Electron Acceptor ITIC-Th via Tailoring its End Groups. Mater. Chem. Front. 2018, 2, 537-543.

(49) Li, T.; Zhang, H.; Xiao, Z.; Rech, J. J.; Niu, H.; You, W.; Ding, L. A Carbon-Oxygen-Bridged Hexacyclic Ladder-type Building Block for Low-Bandgap Nonfullerene Acceptors. Mater. Chem. Front. 2018, 2, 700-703.

(50) Lin, Y.; Zhao, F.; Prasad, S. K. K.; Chen, J. D.; Cai, W.; Zhang, Q.; Chen, K.; Wu, Y.; Ma, W.; Gao, F.; Tang, J. X.; Wang, C.; You, W.; Hodgkiss, J. M.; Zhan, X. Balanced Partnership between Donor and Acceptor Components in Nonfullerene Organic Solar Cells with $>12 \%$ Efficiency. Adv. Mater. 2018, 30, 1706363.

(51) Zhao, F. W.; Wang, C. R.; Zhan, X. W. Morphology Control in Organic Solar Cells. Adv. Energy Mater. 2018, 8, 1703147.

(52) Giridharagopal, R.; Cox, P. A.; Ginger, D. S. Functional Scanning Probe Imaging of Nanostructured Solar Energy Materials. Acc. Chem. Res. 2016, 49, 1769-1776.

(53) Zhu, J. S.; Wu, Y.; Rech, J.; Wang, J. Y.; Liu, K.; Li, T. F.; Lin, Y. Z.; Ma, W.; You, W.; Zhan, X. W. Enhancing the Performance of a Fused-Ring Electron Acceptor via Extending Benzene to Naphthalene. J. Mater. Chem. C 2018, 6, 66-71. 